\title{
Identification of the presence of the mutation of the gene of PKD not associated of HCM in Persian cats - case report
}

\section{Identificação da presença da mutação do gene da PKD não associada a CMH em gatos Persas - relato de caso}

\author{
Vanesa Kutz de Arruda ${ }^{1}$; Mariana Isa Poci Palumbo ${ }^{2}$; Priscilla Macedo de Souza ${ }^{3}$; \\ José Paes Oliveira Filho4; Alexandre Secorun Borges ${ }^{5}$; \\ Maria Lucia Gomes Lourenço ${ }^{*}$
}

\begin{abstract}
Polycystic kidney disease (PKD) is a hereditary autosomal dominant disorder that mainly affects Persian cats; it is an important cause of chronic kidney disease in this species. Hypertrophic cardiomyopathy (HCM) is the most common heart disease in cats, and there is evidence of a genetic origin in some breeds. Although neither of these disorders is rare in cats, according to our literature review, this is the first report of the concomitant occurrence of PKD and HCM in Persian cats in Brazil.
\end{abstract}

Key words: Feline, PKD, HCM, Persian

\section{Resumo}

A doença renal policística (PKD) é uma doença hereditária autossômica dominante que acomete principalmente gatos da raça Persa sendo importante causa de doença renal crônica nesta espécie. A miocardiopatia hipertrófica $(\mathrm{CMH})$ é a doença cardíaca mais comum de gatos, com evidência de origem genética em algumas raças. Apesar de serem doenças frequentemente descritas em gatos, segundo a literatura revisada, este é o primeiro relato da ocorrência concomitante de PKD e CMH em gatos da raça Persa no Brasil.

Palavras-chave: Felino, $\mathrm{PKD}, \mathrm{CMH}$, persa

\footnotetext{
${ }^{1}$ Residente, Dept ${ }^{\circ}$ de Clínica Veterinária, Faculdade de Medicina Veterinária e Zootecnia, UNESP, Botucatu, SP, Brasil. E-mail: vanesa kutz@yahoo.com.br

$2 \operatorname{Prof}^{\mathrm{a}} \mathrm{Dr}^{\mathrm{a}}$, Faculdade de Medicina Veterinária e Zootecnia, UFMS, Campo Grande, MS, Brasil. E-mail: palumboma11@yahoo. com.br

${ }^{3}$ Prof $^{\mathrm{a}}$ Dr $^{\mathrm{a}}$ Serviço de Diagnóstico por Imagem, Sociedade Cultural e Educacional de Garça, FAEF, Garça, SP, Brasil. E-mail: priscillamsvet@gmail.com

4 Profs. Drs. Assistentes, Dept ${ }^{\circ}$ de Clínica Veterinária, Faculdade de Medicina Veterinária e Zootecnia, UNESP, Botucatu, SP, Brasil. E-mail: zefilho@fmvz.unesp.br; mege@fmvz.unesp.br*

${ }_{5}^{5}$ Prof. Adjunto, Dept $^{\mathrm{o}}$ de Clínica Veterinária, Faculdade de Medicina Veterinária e Zootecnia, UNESP, Botucatu, SP, Brasil. E-mail: asborges@fmvz.unesp.br

* Autor for correspondence
} 


\section{Introduction}

Polycystic kidney disease (PKD) is considered the most important genetic disease in cats (YOUNG et al., 2005). It primarily affects Persian and Persian-derived breeds and is characterized by the presence of kidney cysts that affect few nephrons and increase in size as the cats age (EATON et al., 1997). In affected cats, the cysts are associated with compression of the adjacent renal parenchyma and they may be surrounded by fibrous connective tissue (BARRS et al., 2001).

The prevalence of PKD in Persian cats is high, reaching 47\% in Australia (BARRS et al., 2001) and $39 \%$ in the United Kingdom (YOUNG et al., 2005). The disorder is autosomal dominant (AD-PKD) and there are genetic tests that enable identification of animals carrying the genetic mutation, thus facilitating early diagnosis of the disease (YOUNG et al., 2005). The most effective means of eliminating the disease is by evaluating all cats and preventing the reproduction of affected animals; however, owing to the high prevalence of the disease, especially in Persians, this would result in great losses for some breeders (BARRS et al., 2001).

Hypertrophic cardiomyopathy (HCM) is the most common form of heart disease in cats (TREHIOU-SECHI et al., 2012), accounting for approximately $57.5 \%$ of idiopathic cardiac diseases in this species (FERASIN et al., 2003). The disease is characterized by concentric hypertrophy of the ventricular myocardium in the absence of any other obvious cause of hypertrophy, such as systemic hypertension or hyperthyroidism (FERASIN et al., 2003). Autosomal dominant inheritance of a genetic mutation has been documented in Maine Coon (MEURS et al., 2005) and Ragdoll (MEURS et al., 2007) cats. The exact mechanism by which the genetic mutation leads to the development of hypertrophy is not yet clear and familial occurrence of HCM in Persians not described in literature

Clinical manifestations of HCM in domestic cats result from impaired diastolic filling of the left ventricle. Cats with HCM have impaired relaxation and increased ventricular stiffness increases the ventricular diastolic filling pressure and leads to the development of congestive heart failure (pulmonary edema, pleural effusion, dyspnea, lethargy, tachycardia, and tachypnea) (COTÈ et al., 2011). Although neither of the diseases mentioned above are rare in cats, according to our review of the literature, this is the first account of the concomitant occurrence of PKD and HCM in Persian cats. In addition, we here describe a novel genetic mutation of PKD that is not associated with the MYBPC3A31P mutation linked to HCM.

\section{Case report}

A 3-year-old male Persian cat was presented at the School of Veterinary Medicine and Animal Science at the State University of São Paulo, Brazil. The cat had experienced hematuria and pollakiuria for the past 20 days. Upon physical examination, the animal was found to be sensitive to palpation of the bladder and a grade IV/VI systolic murmur was identified in the mitral focus that radiated to the tricuspid focus. A blood sample was taken and the complete blood count (CBC) and levels of ALT, ALP, GGT, BUN, creatinine, total protein, globulin, and albumin were determined. All were within the normal range. The urinalysis returned a density of 1.036 with the presence of occult blood and mild proteinuria $(30 \mathrm{mg} / \mathrm{dL})$ that could be justified by the occult blood. The electrocardiography examination indicated that the sinus rhythm was normal with waves of normal amplitude and duration, a heart rate of $170 \mathrm{bpm}$, and a systolic blood pressure of 150 $\mathrm{mmHg}$. Thoracic radiographic examination revealed biatrial enlargement and dorsal displacement of the trachea (Figure 1A). Abdominal ultrasound images showed bladder wall thickening and multiple cysts of different sizes in the bilateral renal parenchyma (Fig. 1B). Doppler echocardiography revealed diastolic thickening of the interventricular septum 
and left ventricular posterior wall as well as left

which changes that are compatible with HCM (Fig. atrial enlargement (left atrium/aorta $>1.8$ ), all of

1C) (BROWN, GAILLOT, 2013).

Figure 1. (A) Right lateral radiograph showing the enlarged cardiac silhouette and the dorsal deviation of the trachea; (B) Ultrasound sagittal section showing a cyst in the caudal pole of the left kidney measuring $2.35 \times 2.33 \mathrm{~cm}$; (C) Ecocardiodoppler cut in the short axis on the right parasternal window, showing the hypertrophy of the left ventricular wall (between cursors) and decreased left ventricular internal dimension; (D) Right lateral radiograph showing discrete cardiac enlargement; (E) Ultrasound sagittal section showing a cyst in the cortical region of the right kidney measuring $0.74 \times 0.65 \mathrm{~cm}$; (F)Ecocardiodoppler to cut the long axis on the right parasternal window, showing the hypertrophy of the left ventricular free wall and interventricular septum (IVS).

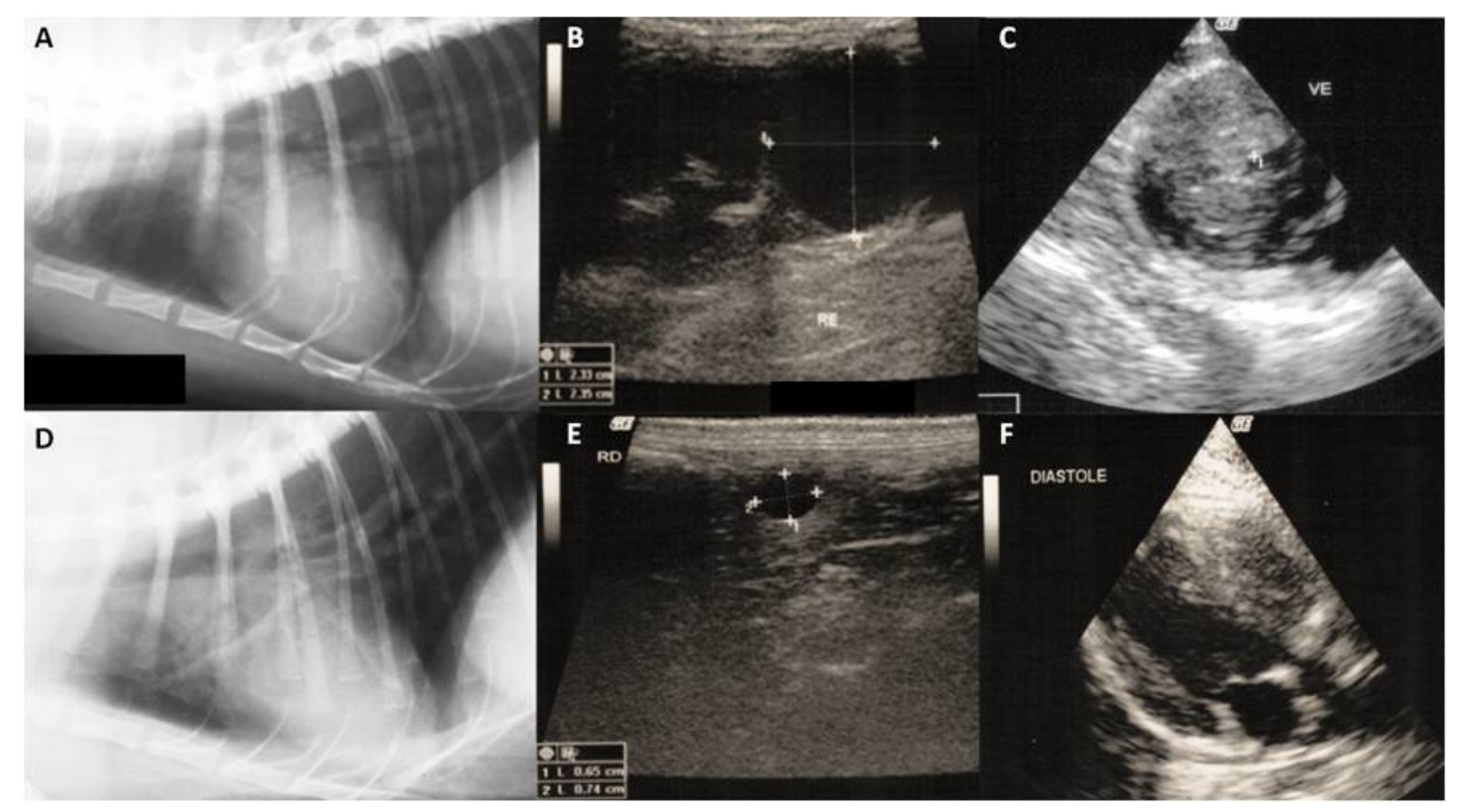

Inflammation of the lower urinary tract was treated with meloxicam $0.1 \mathrm{mg} / \mathrm{kg}$ every $24 \mathrm{~h}$ for 3 days and with food and environmental management; atenolol (8 mg every $12 \mathrm{~h}$ ), fish oil (1 g every 24 h), and acetylsalicylic acid (20 mg/kg every $72 \mathrm{~h}$ ) were also administered. As the suspected diagnosis was hereditary PKD, the progenitor of the animal, an asymptomatic 5-year-old Persian cat, was also examined. The physical examination revealed a mitral systolic murmur (III/VI). Laboratory tests (CBC, urinalysis, and biochemical tests) were all normal. Electrocardiograms revealed a normal sinus rhythm with a normal wave amplitude and duration, a heart rate of $180 \mathrm{bpm}$, and a systemic blood pressure of $140 \mathrm{mmHg}$. Right lateral radiograph showed discrete cardiac enlargement (Figure 1D) and abdominal ultrasound revealed multiple cysts in the corticomedular region (Figure 1E). Doppler echocardiography showed hypertrophy of the interventricular septum and left ventricular posterior wall and high fractional shortening, changes that are compatible with HCM (Figure 1F). Therapy was instituted with atenolol (6.25 mg every $12 \mathrm{~h}$ ) and fish oil ( $1 \mathrm{mg}$ every $24 \mathrm{~h}$ ). The two cats were re-evaluated periodically and, at the last evaluation, which was conducted 6 months after the diagnosis, remained asymptomatic.

Blood samples from the two animals were 
forwarded to the Molecular Biology Laboratory at the School of Veterinary Medicine and Animal Science of the State University of São Paulo to identify the gene responsible for the AD-PKD type 1 mutation in the Persian cats (YOUNG et al., 2005). Since no mutation for HCM has been identified in the Persian breed as yet, the mutation described for the Maine Coon breed (MYBPC3-A31P) (MEURS et al., 2005) was also investigated. The DNA was extracted from the blood samples, amplified by PCR, and the resulting products sequenced. The two cats were found to be heterozygous for the mutation causing PKD in Persians, but the mutation responsible for HCM in Maine Coons was not observed in any of the animals.

\section{Discussion}

Although PKD and HCM occur relatively frequently in cats (BARRS et al., 2001; FERASIN et al., 2003; YOUNG et al., 2005), no other reports of the concomitant incidence of these disorders in the same animal have been published to date. Initially, it was suspected that the cats in this report had chronic kidney disease and that this had led to hypertension and atrial dilation, but the laboratory tests ruled out this possibility. In addition, none of the cats presented with arterial hypertension, which suggests that these symptoms were evidence of individual renal and cardiac diseases.

Cats with PKD have a progressive disorder that can reach end-stage renal disease at 3 years of age and slowly evolve for many years thereafter, becoming evident at close to 10 years of age (BARRS et al., 2001). None of the cats in this report showed signs of chronic kidney disease at the time of the diagnosis of PKD despite both already being in the age group predisposed to the development of clinical signs (BARRS et al., 2001).

Bothcats were males, which supports the literature showing that male cats are more predisposed to the development of HCM (TREHIOU-SECHI et al., 2012). The murmur evidenced during cardiac auscultation of the animals is a change commonly seen in cats with HCM (36 a 72\%) (COTÈ et al., 2011). In few affected cats, sudden death may occur without any previous clinical signs (ABBOTT, 2010). In our case, both animals were asymptomatic at the time of diagnosis, which enabled early treatment and will probably increase their median survival.

Abdominal ultrasound is a noninvasive, fast, sensitive, and highly specific method for identifying cats with PKD and it permits detection of the illness in young cats aged 6 to 7 weeks. However, the absence of PKD at an early age does not mean that the animal cannot develop cysts as it ages (BARRS et al., 2001). Genetic tests are a safe and accurate means of identifying affected animals before they reproduce (YOUNG et al., 2005). The PKD in the cats that are the subject of this report was diagnosed by ultrasonography and by identification of the ADPKD type 1 mutations.

A definitive diagnosis can be achieved by echocardiography (TREHIOU-SECHI et al., 2012), and is based on the presence of ventricular hypertrophy, which is often associated with other changes, such as hyperdynamic ventricular function, and left atrium or biatrial dilation (FERASIN et al., 2003). There are at present no genetic tests for identifying HCM in Persian cats because no specific mutation has been identified in this breed to date. In the present study, a test was performed to determine whether the same mutation was responsible, as has been described for Maine Coon cats, but the results were negative. This was expected because the MYBPC3 mutation A31P seems to be specific to that breed (MARY et al., 2010). Moreover, some authors have suggested that this mutation is not the only cause of HCM in cats (KITTLESON et al., 2010).

It is recommended that all Persian and Persianderived breeds be tested for PKD before they are allowed to reproduce (CANNON et al., 2001). Further research to identify the causative HCM 
mutation in the Persian breed is crucial for enabling early diagnosis and for minimizing reproduction of affected animals.

\section{Conclusion}

The present case report of the concomitant occurrence of PKD and HCM in Persian cats suggests that a genetic mutation for HCM may also be present in Persians despite the fact that, to date, no gene encoding such a mutation has been described for this breed, and genetic alteration (MYBPC3-A31P) be specifically designated in the breed Maine Coon. Early identification of affected animals is fundamental for controlling the spread of the disease and any cats that carry the mutated gene should not be bred.

\section{References}

ABBOTT, J. A. Feline hypertrophic cardiomyopathy: an update. The Veterinary Clinics of North America. Small Animal Practice, Salt Lake, v. 40, n. 6, p. 685-700, 2010.

BARRS, V. R.; GUNEW, M.; FOSTER, S. F.; BEATTY, J. A.; MALIK, R. Prevalence of autosomal dominant polycystic kidney disease in Persian cats and relatedbreeds in Sydney and Brisbane. Australian Veterinary Journal, United Kingdom, v. 79, n. 4, p. 257-259, 2001.

BROWN, D.; GAILLOT, H. Heart. In: DOMINIQUE, P. Atlas of small animal ultrasonography. $3^{\text {th }}$ ed. Iowa: Wiley-Blackwell, 2013. p. 149-214.

CANNON, M. J.; MACKAY, A. D.; BARR, F. J.; RUDORF, H.; BRADLEY, K. J.; GRUFFYDD-JONES, T. J. Prevalence of polycystic kidney disease in Persian cats in the United Kingdom. The Veterinary Record, London, v. 149, n. 14, p. 409-411, 2001.

COTÈ, E.; MACDONALD, K. A.; MEURS, K. M.; SLEEPER, M. M. Hypertrophic cardiomyopathy. In: 2011.p. 103-181. Feline cardiology. Iowa: Wiley-Blackwell,

EATON, K. A.; BILLER, D. S.; DIBARTOLA, S. P.; RADIN, M. J.; WELLMAN, M. L. Autosomal dominant polycystic kidney disease in Persian and Persian-cross cats. Veterinary Pathology, Winterthur, n. 34, n. 2, p. 117-126, 1997.
FERASIN, L.; STURGESS, C. P.; CANNON, S. M. A.; CANEY, S. M.; GRUFFYDD-JONES, T. J.; WOTTON, P. R. Feline idiopathic cardiomyopathy: a retrospective study of 106 cats (1994-2001). Journal of Feline Medicine and Surgery, London, v. 5, n. 3, p. 151-159, 2003.

KITTLESON, M. D.; MEURS, K.; MUNRO, M. Letter to the editor. Association of A31P and A74T polymorphisms in the myosin binding protein $\mathrm{C} 3$ gene and hypertrophic cardiomyopathy in Maine Coon and other breed cats. Journal of Veterinary Internal Medicine, Hoboken, v. 24, n. 3, p. 1242-1243, 2010.

MARY, J.; CHETBOUL, V.; SAMPEDRANO, C. C.; ABITBOL, M.; GOUNI, V.; TREHIOU-SECHI, E.; TISSIER, R.; QUENEY, G.; POUCHELON, J. L.; THOMAS, A. Prevalence of the MYBPC3-A31P mutation in a large European feline population and association with hypertrophic cardiomyopathy in the Maine Coon breed. Journal of Veterinary Cardiology, New York, v. 12, n. 3, p. 155-161, 2010.

MEURS, K. M.; NORGARD, M. M.; EDERER, M. M.; HENDRIX, K. P.; KITTLESON, M. D. A substitution mutation in the myosin binding protein $\mathrm{C}$ gene in ragdoll hypertrophic cardiomyopathy. Genomics, Boston, v. 90, n. 2, p. 261-264, 2007.

MEURS, K. M.; SANCHEZ, X.; DAVID, R. M.; BOWLES, N. E.; TOWBIN, J. A.; REISER, P. J.; KITTLESON, J. A.; MUNRO, M. J.; DRYBURGH, K.; MACDONALD, K. A.; KITTLESON, M. D. A. cardiac myosin binding protein $\mathrm{C}$ mutation in the Maine Coon cat with familial hypertrophic cardiomyopathy. Human Molecular Genetics, New York, v. 14, n. 23, p. 35873593, 2005.

TREHIOU-SECHI, E.; TISSIER, R.; GOUNI, V.; MISBACH, C.; PETIT, A. M.; BALOUKA, D.; SAMPEDRANO, C. C.; CASTAIGNET, M.; POUCHELON, J. L.; ChETBOUL, V. Comparative echocardiographic and clinical features of hypertrophic cardiomyopathy in 5 breeds of cats: a retrospective analysis of 344 cases (2001-2011). Journal of Veterinary Internal Medicine, Ohio, v. 26, n. 3, p. 532-541, 2012.

YOUNG, A. E.; BILLER, D. S.; HERRGESELL, E. J.; ROBERTS, H. R.; LYONS, L. A. Feline polycystic kidney disease is linked to the PKD1 region. Mammalian genome, New York, v. 16, n. 1, p. 59-65, 2005. 
